3. Korotkov, I. S. (2009). Media as the ultimate experience. V.V. Savchuk, M.A. Stepanova. (Eds.) Media Philosophy II: Boundaries of discipline. St. Petersburg : Publishing House of the St. Petersburg Philosophical Society, 39-42 [in Russian].

4. Kiuru, K.V. (2017). Modern media discourse: digitization of media text and the problem of genre formation. Materials of the All-Russian scientific-practical conference with international participation. Yekaterinburg: Izvestiya Ural. Un-ta, 243-245 [in Russian].

5. Manovich, L. (2002). The Language of New Media. London : The MIT Press, Cambridge, Massachusetts, 49-65 [in English].

6. Shayhitdinova, S.K. (2009). Dual and Medial Structure in Culture. V.V. Savchuk, M.A. Stepanova (Eds.). Media Philosophy II: Boundaries of discipline. St. Petersburg : Publishing House of the St. Petersburg Philosophical Society, 35-38 [in Russian].

7. Sokolova, N.L. (2011). Transmedia and "interpretive communities". International Journal of Cultural Research. St. Petersburg : Eidos, 3(4), 16-21 [in Russian].

8. Fljusser, V. (2009). About projecting . Chora. Journal of modern foreign philosophy and philosophical comparativistics (pp. 65-76) issue. 3/4, (9/10) [in Russian].

9. Flusser, V. (1998). Vom Subjekt zum Projekt. Menschwerdung. M., Fr. am, 217 [in German].

10. Flusser, V. (1990). Eine neue Einbildungskraft. Bildlichkeit. Internationale Beiträge zur Poetik. Hrsg.von V. Bohn. M., Fr. am., 125 [in German].

11. Zhurba, M.A. \& O. V. Pagava, \& V.V. Baidyk (2016). Labyrinths of virtual: Theseus in search of Ariadne: monograph. Kharkiv: Publishing house Tochka [in Ukrainian].

UDC 37.02:004

\author{
Karpenko Oleksandr \\ DSc (Public Administration), \\ Chairman of Information Policy and \\ Digital Technologies faculty, \\ National Academy of Public Administration, \\ under the President of Ukraine, \\ ORCID 0000-0002-9301-7973; \\ dr.karpenko@ukr.net \\ Glubochenko Kateryna \\ $\mathrm{PhD}$ in Public Administration, \\ V. O. Sukhomlynskyi Mykolaiv \\ National University \\ ORCID 0000-0003-1490-0643 \\ t_ekaterina@ukr.net
}

\title{
THE CONCEPT OF CULTURAL COMPETENCE OF THE DIGITAL GOVERNANCE SPECIALISTS WITHIN PUBLIC ADMINISTRATION
}

The purpose of this article is to define and analyze the concept of cultural competence of the digital governance specialists in the public administration science. The methodological bases of the research are the methods of observation and comparative analysis that allow to systematize important factors of cultural competence assessment of digital governance specialists. Scientific novelty of the article consists of the identification of the digital governance specialists' cultural competence concept in public administration and defining the elements of its assessment. Conclusions. Cultural competence based on developed communication skills makes digital governance more effective, because corresponding knowledge and communication skills help service delivery agencies to solve the majority of internal and external conflicts within the public administration system. The main advantage of intercultural communication skills development is the improvement of services delivery process and the increase in efficiency of interactions between citizens and public administration institutes via mechanisms of digital governance. Considering global experience in digital governance implementation, conclusions and recommendations for Ukraine were made.

Keywords: Cultural Competence, Communication Skills, Digital Governance, Digital Governance Specialists, Cultural Competence Assessment.

Карпенко Олександр Валентинович, доктор наук з державного управління, завідувач кафредри інфрормаційної політики та цифрових технологій Національної академії державного управління при Президентові України; Глубоченко Катерина Олександрівна, кандидат наук з державного управління, доцент кафедри менеджменту організацій та зовнішньоекономічної діяльності Миколаївського національного університету імені B.О. Сухомлинського управління

Концепція культурної компетентності спеціалістів з цифрового врядування у системі державного

(c) Karpenko O., 2018

(c) Glubochenko K., 2018 
Метою даної статті є визначення та аналіз концепції культурної компетентності спеціалістів з цифрового врядування у науці державного управління. Методологічною основою дослідження є методи спостереження та порівняльного аналізу, які дозволили систематизувати важливі фрактори оцінювання культурної компетентності спеціалістів з цифрового врядування. Наукова новизна полягає в ідентифікації концепції культурної компетентності спеціалістів з цифрового врядування у системі державного управління та визначенні елементів її оцінювання. Висновки. Доведено, що культурна компетентність, що ґрунтується на відповідних комунікативних вміннях та навичках спеціалістів, підвищує ефективність цифрового врядування, адже розвиток відповідних вмінь допомагає в процесі надання управлінських послуг вирішити більшість внутрішніх та зовнішніх конфліктів. Головною перевагою розвитку міжкультурних комунікативних вмінь та навичок є підвищення ефективності взаємодії між громадянами та державними службовцями за допомогою механізмів цифрового врядування. Враховуючи міжнародний досвід впровадження цифрового врядування, були розроблені висновки та рекомендації для системи державного управління в Україні.

Ключові слова: культурна компетентність, комунікативні навички, цифрове врядування, спеціалісти 3 цифрового врядування, оцінювання культурної компетентності.

Карпенко Александр Валентинович, доктор наук государственного управления, заведующий кафедрой информационной политики и цифровых технологий Национальной академии государственного управления при Президенте Украины; Глубоченко Екатерина Александровна, кандидат наук государственного управления, доцент кафедры менеджмента организаций и внешнеэкономической деятельности Николаевского национального университета имени В.А. Сухомлинского

Концепция культурной компетентности специалистов цифрового управления в системе государственного управления

Целью данной статьи является определение и анализ концепции культурной компетентности специалистов цифрового управления в науке государственного управления. Методологической основой исследования являются методы наблюдения и сравнительного анализа, которые позволили систематизировать важные фракторы оценивания культурной компетентности специалистов цифрового управления. Научная новизна заключается в идентификации концепции культурной компетентности специалистов цифрового управления в системе государственного управления и определении элементов ее оценивания. Выводы. Доказано, что культурная компетентность, которая основывается на соответствующих коммуникативных умениях и навыках специалистов, повышает эффективность цифрового управления, поскольку развитие данных умений помогает в процессе оказания управленческих услуг решить большинство внутренних и внешних конфликтов. Главным преимуществом развития межкультурных коммуникативных умений и навыков является повышение эффективности взаимодействия между гражданами и государственными служащими при помощи механизмов цифрового управления. Учитывая международный опыт внедрения цифрового управления, были сделаны выводы и предложены рекомендации для системы государственного управления в Украине.

Ключевые слова: культурная компетентность, коммуникативные навыки, цифровое управление, специалисты цифрового управления, оценивания культурной компетентности.

The relevance of the study. Diversity in the Information Age is permanently increasing, so, it becomes imperative for the e-Governance (digital governance) specialists to be culturally competent in order to provide the service delivery to the diverse clients within multicultural regions effectively. Population census (2001) in Ukraine revealed that 27,3 percent of Ukrainian citizens belong to different national minorities. So, almost the third part of public services recipients are non-Ukrainians, though they are citizens of Ukraine. The most widespread minorities are Russians, Romany, Jews, Crimean Tatars, Belarusians, Hungarians, Armenians, Greeks, Poles, Romanians, and others. The lack of cultural competence of the specialists leads to increase in social contradictions, as well. National and cultural based conflicts in Ukraine are also extremely complicated nowadays. However, this issue is not investigated enough in the public administration science yet. So, the understanding of the digital governance specialists' cultural competence in the public administration and the development of the concept is a relevant and necessary direction of modern studies in the area of e-Governance and the service delivery digitalization.

Literature overview. The issue of cultural competence in public administration is being analyzed in several directions, such as interactions between elected officials and digital technologies specialists, citizens and e-Governance specialists, citizens and service delivery agencies. A lot of studies reveal reluctance of digital technologies implementation manifested by service delivery specialists. According to Perri (2004), the main challenge of information technology industry is "to design for actual form of social relationships between policy makers" $[8,11]$. The author points out, that policy makers use digital technologies because of the political reasons, so, such attitude to digital technologies leads to "the slow take-up of many egovernance tools". Singh (2013) also highlights 'the obstruction' to implement the new form of administration among elected officials. However, the author points out that such opposition is not able "to prevent coming of the ICT-based governance" [11, 172]. On the other hand, not only officials, but also citizens have a lack of cultural competence in the engagement of digital technologies of service delivery. OECD's report highlights that "some citizens seem inherently or culturally unable to engage with digital technologies" [7, 39]. So, citizens' resistance in the new forms of administration can influence the efficiency of this process.

The concept of the cultural competence in different social areas has a lot of meanings. However, the definition of Cross (1988) seems to be the most widespread. According to the author, "cultural competence is a set of corresponding policies, behaviors, and attitudes that come together in the professionals, agencies and systems, and enable that systems, professionals or agencies to work efficiently in cross-cultural situa- 
tions" [2, 2]. So, the understanding of not only own culture, but also perceiving the cultural differences can help to avoid the majority of cultural based contradiction in modern society. Thus, all the areas of the public administration system, including e-Governance and service delivery digitalization need the development of the cultural competence. The studies of Kovačić (2005), Primm et.al. (2005), Sereni-Massinger \& Wood (2016), and others also contribute to this issue. However, there is no common concept of cultural competence of the digital governance specialists in public administration still.

The purpose of the article is to define and analyze the concept of cultural competence of the digital governance specialists in the public administration science.

Research results. According to Heine (2010), "people's self-concepts, language use, cognition, personalities, relationships, perception, motivation, moral reasoning and emotions are shaped by their culture" $[4,1423]$. So, cultural competence as a part of communicative competence allows to provide any social activity more effectively. E-Governance as a significant institute of the public administration system has a special role in this process. According to Primm et.al. (2005), "the effect of cultural dissonance" in providing services by service agencies forms an essential problem [9, 557]. National and cultural differences often have a tendency to extend some social stereotypes of the cultural backgrounds to all the cultural group. That leads to escalation of misunderstandings based on the cultural differences. E-Governance aims to less direct human interactions between the client and service delivery agencies. However, digital background can also contain significant examples of cultural incompetence of its developers. So, it is necessary to develop cultural competence within the e-Governance area in public administration in order to avoid the unethical and injustice treatment of the citizens. Digital governance specialists should be culturally competent, as well as other officials, within public administration system. That is the way to cope with bureaucracy and controversy, and to provide effective service delivery within multinational Ukrainian regions (especially Western Ukrainian border territories). Stakeholders of the public administration system themselves are the representatives of different nationalities and cultures. Thus, the development of cultural competence within the public administration system can help specialists in e-Governance and service delivery to overcome internal cultural barriers in addition to external ones.

So, the development of cultural competence in the digital governance field needs special trainings and education in order to get necessary communication skills and knowledge. According to SereniMassinger \& Wood (2016), "police agencies that pay attention to diversity education and familiarizing their services providers with cultural differences are more inclined to solve conflicts and prevent crimes" [10, 259]. Such tendency is relevant for other fields of service delivery, as well. Thus, training programs and education in cultural diversity is necessary and important for digital governance specialists and other officials in order to be effective enough within a multinational region.

So, the development of cultural competence via educational and training programs is the first significant element of the cultural competence assessment of a service delivery agency. Self-assessment of the learned outcomes is also necessary to monitor. The second element that should be included in the analysis of cultural competence is the access to the digital governance services for different national, social, and cultural groups. Effectiveness of digital interactions with citizens of different cultural groups also should be evaluated. The third one is the effective cross-cultural management of interactions between all the service delivery providers in a region. So, obviously, inclusion of experts (for instance, leaders of the national organizations or training specialists), in a digital governance team can reduce conflicts between the representatives of different nationalities and cultures.

The main advantages of cultural competence development and the improvement of intercultural communication skills are the improvement of services delivery and effectiveness of collaboration between public service agencies and different cultural groups within a region. Such skills give service delivery providers the opportunities to increase in the efficiency of digital governance. According to Kovačić (2005), eGovernment readiness of different countries is influenced by national cultural indicators such as Individualism and Power Distance [6, 156]. Digital skills training for public servants are the most effective way to provide understanding between digital experts and government [3].

Such strategy is relevant for Ukraine as well, because, in order to transform the public administration system in Ukraine via 'digitalization', the "Digital agenda for Ukraine 2020" was developed. This strategy offers ten strategic technologies ("Digital Workplace", "Multichannel Informing and Citizen Engagement", "Public Data", "Electronic Identification", "Internet of Things", "Digital Platforms", "Software Architectures", "Blockchain") in order to change the public administration system in Ukraine [1,53-55]. At the same time, according to Hermann et.al. (2015), Internet of Services (IoS) allows service providers to integrate their services via network services chain system [5, 9-10]. So, with the view to developing necessary cultural competence skills as an element of digital literacy in the area of managerial innovations and improving the level of professional growth within training skills system it is necessary to modernize the system of re-education of service providers (civil servants) in Ukraine. National Academy for Public Administration under the President of Ukraine is special institution, which is implementing of this strategy, involving in educational process leading manufacturers of digital technologies and complex information solutions (Google, Microsoft, Cisco, Amazon, SAP, IBM, Intel, Oracle, Deloitte etc.) via organizing corresponding trainings with certification of participants, including trainings in cultural competence. 
In 2001 the Chair of Information Policy was created in the structure of National Academy. In spite of changing its title (Chair of Information Policy $\rightarrow$ Chair of Information Policy and Technologies $\rightarrow$ Chair of Information Policy and e-government), the Chair has been contributing to the development of Ukrainian information society via training of qualified specialists in master degree graduation and postgraduate and doctorate studies in "Public Administration". Such specialists, obtaining a set of personal, social, cultural, and professional competencies according to European education standards and The Bologna Process, are able to provide information policy and digital governance effectively.

Unavoidable digitalization of public administration requires new creative and innovation-minded specialists, who specialize in completely different, modern activities. So, it is necessary to improve education process permanently according to modern requirements. By 2021 the Chair is going to be leading innovative subdivision of the National Academy, using effective integration of research, methodical and expert directions in order to implement the Strategy for reforming of the National Academy 2017-2021. During 20172019 the Chair is carrying out the research "Digital Strategy of the EU as basis of formation of serviceoriented policy in Ukraine". The purpose of this research is to provide a theoretical rationale of foreign experience implementation of service-oriented digital governance in Ukrainian background, determination of main priorities, objectives and mechanisms of this process. In the context of digital transformation in Ukrainian public administration it seems to be logical to change the title of the Chair. That will give opportunities to coincide the results of educational process and public administration's needs in competitive specialists, to activate management of career development of Graduates, to determine its image for current students, graduates and future entrants. All things concerned, scholars of the Chair initiated the process of changing the Chair title from "The Chair of Information Policy and e-Government" to "The Chair of Information Policy and Digital Technologies". That allows to match it with directions of educational and scholar activities and to correspond the modern paradigm of public administration in Ukraine.

Scientific novelty. The scientific novelty of the study consists of the identification by the authors of the concept of cultural competence of the digital governance specialists in public administration and defining the elements of its assessment. The authors also analyze the foreign experience and offer the direction of its implementation in Ukrainian digital governance and service delivery system.

Conclusions. The main conclusion to be drawn from this discussion is that cultural competence based on developed communication skills makes the digital governance more effective. Cross-cultural interactions within modern society are widespread phenomena. So, special knowledge and communication skills in the area can help service delivery agencies to solve the majority of internal and external conflicts within the public administration system. Therefore, special training programs in the directions of cultural diversity and communications is a key factor for service delivery agencies to accomplish their activities more effectively. The main advantage of intercultural communication skills development is the improvement of services delivery and the increase in efficiency of interactions between citizens and public administration institutes via mechanisms of digital governance.

Considering global experience in digital governance implementation, the authors offer the next conclusions and recommendations for Ukraine:

1. Digitalization becomes global trend and key driver of The Fourth Industrial Revolution "Industry 4.0". Digital agenda must become foundation of the development of independent governance in Ukraine, whereas modern managerial inclusiveness should be based on digital standards (according to principle of "Digital by Default"), so that all transaction of public administration service activities are being provided only in digital (electronic) format.

2. According to civil concept of "Digital Agenda 2020" in order to form independent regulatory ensuring of digital governance in Ukraine it is recommended to develop and adopt such documents as: "National Strategy for Digitalization Development" (Decree of the President of Ukraine), and "National Program for Digitalization" (the Law) instead of current "National Program for Informatization" (according to the Law of Ukraine of February 04, 1998 № 74/98-VR), which is not relevant anymore and does not correspond to the basic principles of the global digital society in conditions of cultural diversity. Then it would be expediently to adopt at the subordinate level corresponding plans (short-term and long-term) in order to implement digital activities in Ukraine. Adoption of mentioned legal framework will give the opportunities to implement basic goals and objectives of Strategy for Sustainable Development "Ukraine - 2020", which was approved by Decree of the President of Ukraine of January 12, 2015 № 5/2015.

3 . In the context of institutional ensuring of digital transformation, the authors offer to create the Ministry of Information Policy of Ukraine and Public Agency on issues of e-Governance of Ukraine in order to implement digital governance and effective public policy of digitalization in Ukraine, to regulate digital economy: manufacturing, implementation and use of digital technologies in the industry, culture, education, medicine, agriculture and so on.

4. In the context of digital (electronic) payments increase, it was defined that the main motivation to transfer from cash to cashless payments is depreciation of every electronic transaction in order to make them cheaper. Besides, it is important to increase the level of culture to use the digital payments among citizens via organizing of corresponding information campaign in Ukraine. 
5. Developing complex digital solutions for providing the service delivery, digital governance specialists should take into account their target audience, in particular nationality, culture, language and educational background. Special trainings in cultural competence for digital governance specialists within the National Academy for Public Administration under the President of Ukraine are considered as a way to obtain necessary knowledge in this area.

\section{תimepamypa}

1. Цирррова адженда України - 2020 (“Цифрровий порядок денний” - 2020) / Концептуальні засади (версія 1.0) // Hiteh-office. 2016. 90c.

№ 3. - P.1-9.

2. Cross T. Services to minority populations / T. Cross // Cultural competence continuum. Focal Point. - 1988.-

3. Department for Digital, Culture, Media \& Sport. Digital government - maintaining the UK government as a world leader in serving its citizens online. URL: https://www.gov.uk/government/publications/uk-digital-strategy/6-digitalgovernment-maintaining-the-uk-government-as-a-world-leader-in-serving-its-citizens-online

2010.

4. Heine S. J. Cultural psychology. Handbook of Social Psychology. Hoboken, NJ: John Wiley \& Sons, Inc,

5. Hermann M. Design principles for Industrie 4.0 scenarios: A literature review. Technische Universitat Dortmund. Working Paper. 2015. № 1. P.1-16.

6. Kovačić Z. J. The impact of national culture on worldwide eGovernment readiness. Informing Science Journal. 2005. №8. P.143-158.

7. OECD. Digital government strategies for transforming public services in the welfare areas. URL: http://www.oecd.org/gov/digital-government/Digital-Government-Strategies-Welfare-Service.pdf

8. Perri P. E-governance styles of political judgement in the Information Age polity. New York, NY: Palgrave Macmillan, 2004.

9. Primm A.B. Race and ethnicity, mental health services and cultural competence in the criminal justice system: Are we ready to change? Community Mental Health Journal. 2005. №41(5). P. 557-569.

10. Sereni-Massinger C. Improving law enforcement cross cultural competencies through continued education. Journal of Education and Learning. 2016. №5(2). P. 258-264.

11. Singh A. A critical impulse to e-Governance in the Asia Pacific. New Delhi, India: Springer, 2013.

\section{References}

1. Digital Agenda for Ukraine - 2020 (“Digital Agenda” - 2020): Conceptual principles (version 1.0). (2016). Hiteh-office [in Ukrainian]. English].

2. Cross, T. (1988). Services to minority populations. Cultural competence continuum. Focal Point, 3, 1-9 [in

3. Department for Digital, Culture, Media \& Sport. (2017). Digital government - maintaining the UK government as a world leader in serving its citizens online. Retrieved from https://www.gov.uk/government/publications/uk-digitalstrategy/6-digital-government-maintaining-the-uk-government-as-a-world-leader-in-serving-its-citizens-online [in English].

4. Heine, S. J. (2010). Cultural psychology. In Handbook of Social Psychology. Hoboken, NJ: John Wiley \& Sons, In. [in English].

5. Hermann, M., Pentek, T. \& Otto, B. (2015). Design principles for Industrie 4.0 scenarios: A literature review. Technische Universitat Dortmund. Working Paper, 1, 1-16 [in English].

6. Kovačić, Z. J. (2005). The impact of national culture on worldwide eGovernment readiness. Informing Science Journal, 8, 143-158 [in English].

7. OECD. (2016). Digital government strategies for transforming public services in the welfare areas. Retrieved from http://www.oecd.org/gov/digital-government/Digital-Government-Strategies-Welfare-Service.pdf [in English].

8. Perri, P. (2004). E-governance styles of political judgement in the Information Age polity. New York, NY: Palgrave Macmillan [in English].

9. Primm, A.B., Osher, F.C. \& Gomez, M.B. (2005). Race and ethnicity, mental health services and cultural competence in the criminal justice system: Are we ready to change? Community Mental Health Journal, 41, 5, 557-569 [in English].

10. Sereni-Massinger, C. \& Wood, N. (2016). Improving law enforcement cross cultural competencies through continued education. Journal of Education and Learning, 5(2), 258-264 [in English].

11. Singh, A. (2013). A critical impulse to e-Governance in the Asia Pacific. New Delhi, India: Springer [in English]. 